\title{
Analysis of Sound Produced by a Traditional Malay Musical Instrument "Kompang"
}

\author{
A.E Ismail ${ }^{1, a^{*}}$, K.A. Arif ${ }^{1, b}$, M.N. Yahya ${ }^{1, d}$, W.A. Siswanto ${ }^{1, \mathrm{e}}$, I. Nawi $^{1, \mathrm{f}}$ \\ ${ }^{1}$ Dept. Engineering Mechanics, Faculty of Mechanical and Manufacturing Engineering, Universiti \\ Tun Hussein Onn Malaysia, Parit Raja 86400, Johor, Malaysia \\ aemran@uthm.edu.my, bkhroolash@yahoo.com, 'musli@uthm.edu.my, ewaluyo@uthm.edu.my, \\ ismailn@uthm.edu.my
}

Keywords: Musical Acoustics, Kompang, Traditional Musical Instrument, Sound Characteristics.

\begin{abstract}
This paper presents frequency analyses of sounds produced by traditional Malay musical instrument "kompang". Kompang is used to produce exotic sound especially certain grand ceremony. In order to produce sound, different types of skins are used especially made from polymer (used x-ray film) and animal skins. However, the sound produced by a polymeric skin is not similar with the sound produced using an animal skin. Therefore, this present work investigated the effect of such skins on the sound produced and as a result affecting the sound quality. Appropriated software is used to conduct the frequency analyses in order to investigate whether the polymeric skin can be a replaceable skin in replacing an animal skin. It is found two different skin materials have their own sound characteristics and it is also indicated that lower peak sound frequency produced by animal skin compared with the polymeric skin.
\end{abstract}

\section{Introduction}

Kompang is one of traditional musical percussion instruments as shown in Fig. 1(a) that can produce sound by beating the constrained membrane with palm hand as in Fig. 1(b). The sheet of the membrane of traditional kompang can be made of goat or cow skin, while the cylindrical frame is made of wood. Rotten tie is used to tight the sheet and frame.

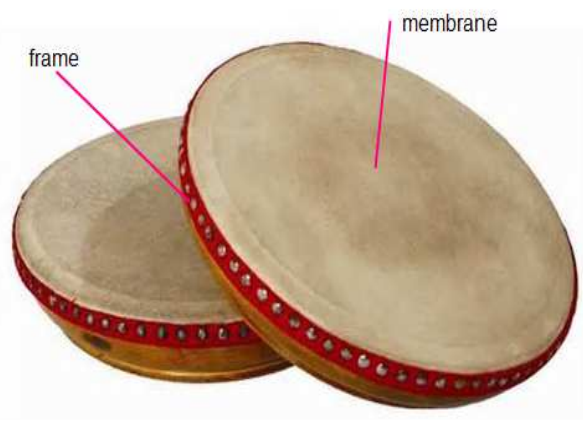

(a)

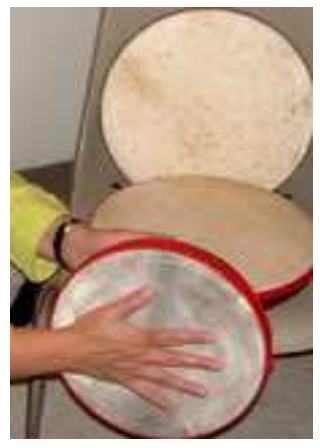

(b)

Fig 1. (a) Percussion instrument kompang and (b) Beating a membrane with a palm hand.

Kompang is not only a musical instrument but it is part of traditional culture practiced in some states in Malaysia when celebrating the brides in wedding ceremony. The unique sound of kompang played in ensemble creates a joyful and happy environment in the wedding ceremony. The rhythm of sound almost same in every wedding ceremony and it is usually played by a group of people. There are only two basic ways to produce kompang sounds: the first is Pak and the second Bung. The Pak sound is produced when the beating is in the middle of kompang skin membrane by the whole palm. The Bung sound is produced when the beating is at the outer part of the membrane by using four fingers altogether.

Research works on kompang can be found elsewhere [1,2]. Ismail et al. [1] stated that large frequency occurred when the center strike is used when compared with the edge strike. While, 
Senan et al. [2] focused on the sound classifications and enhancements using feature selection algorithm. In this paper reports the preliminary results on the frequency analyses and responses of the kompang using two types of skins (polymer and animal skins). The goal is to compare the sound characteristics using both types of skins.

\section{Methodology}

A schematic diagram of kompang is shown in Fig. 1(a) It is consisted of three main components such Baluh, Muka and skin. Two variations of kompang are produced according to the geometry of diameters $(320$ and $200 \mathrm{~mm})$ and thicknesses $(60$ and $50 \mathrm{~mm})$. Two types of sounds can be produced depending on the way of beating the skin called "Bung" and "Pak" as in Fig. 1(b) and 1(c). Two type of membrane skins are used for a comparison purposes such as animal (goat) and polymeric (x-ray film) skins. In order to have proper sound level produced by the Kompang, the disturbing frequencies are omitted from the analysis by measuring the absolute sound amplitude inside and outside studio. Fig. 2 shows the absolute sound amplitude inside and outside studio. The sound is recorded according to Fig. 3. The sound is recorded using two software: Spectraplus DT and Sonar X2. The recorded sound is then analyzed using frequency analyzer software. The frequency analysis technique of traditional musical instrument is similar with that from Siswanto et al. [3].

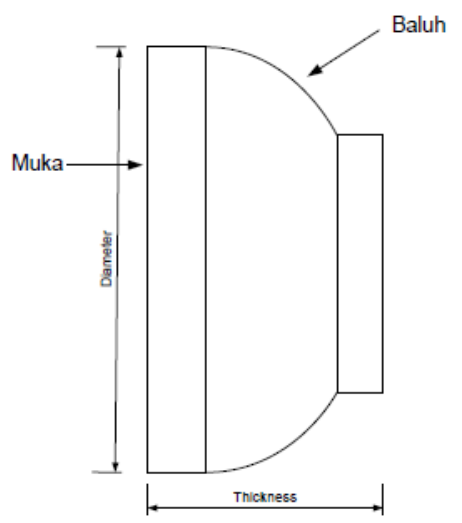

(a)

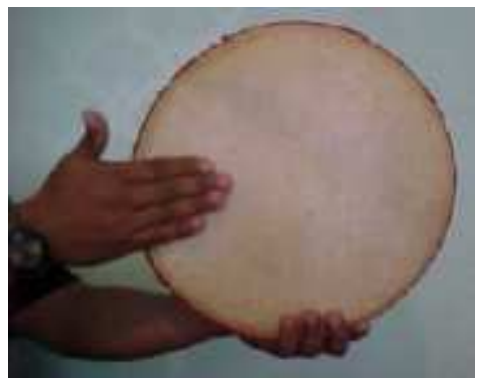

(b)

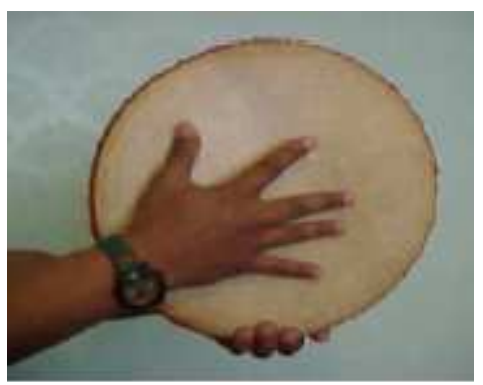

(c)

Fig. 1 (a) Schematic diagram of kompang, (b) Beating the skin to produce sound "bung" and (c)

Beating the skin to produce sound "pak".

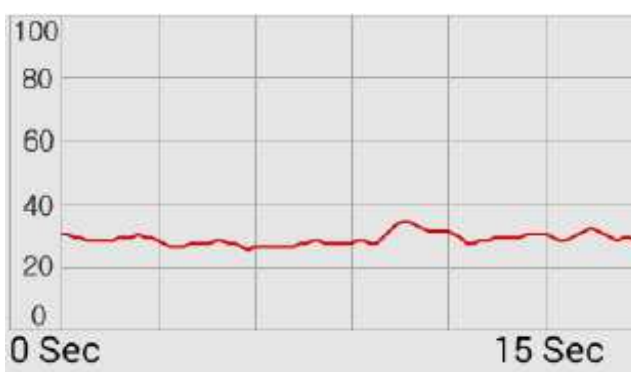

(a)

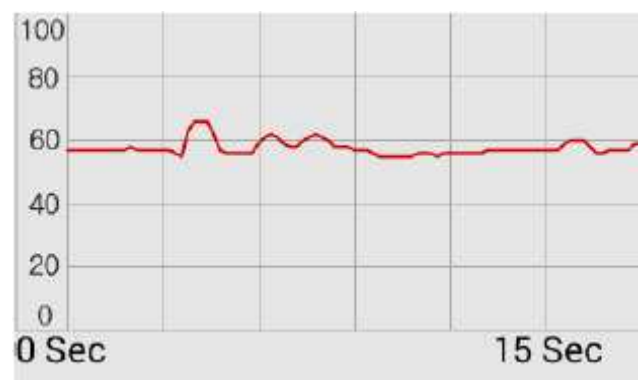

(b)

Fig. 2 The absolute sound amplitude inside and outside studio. 


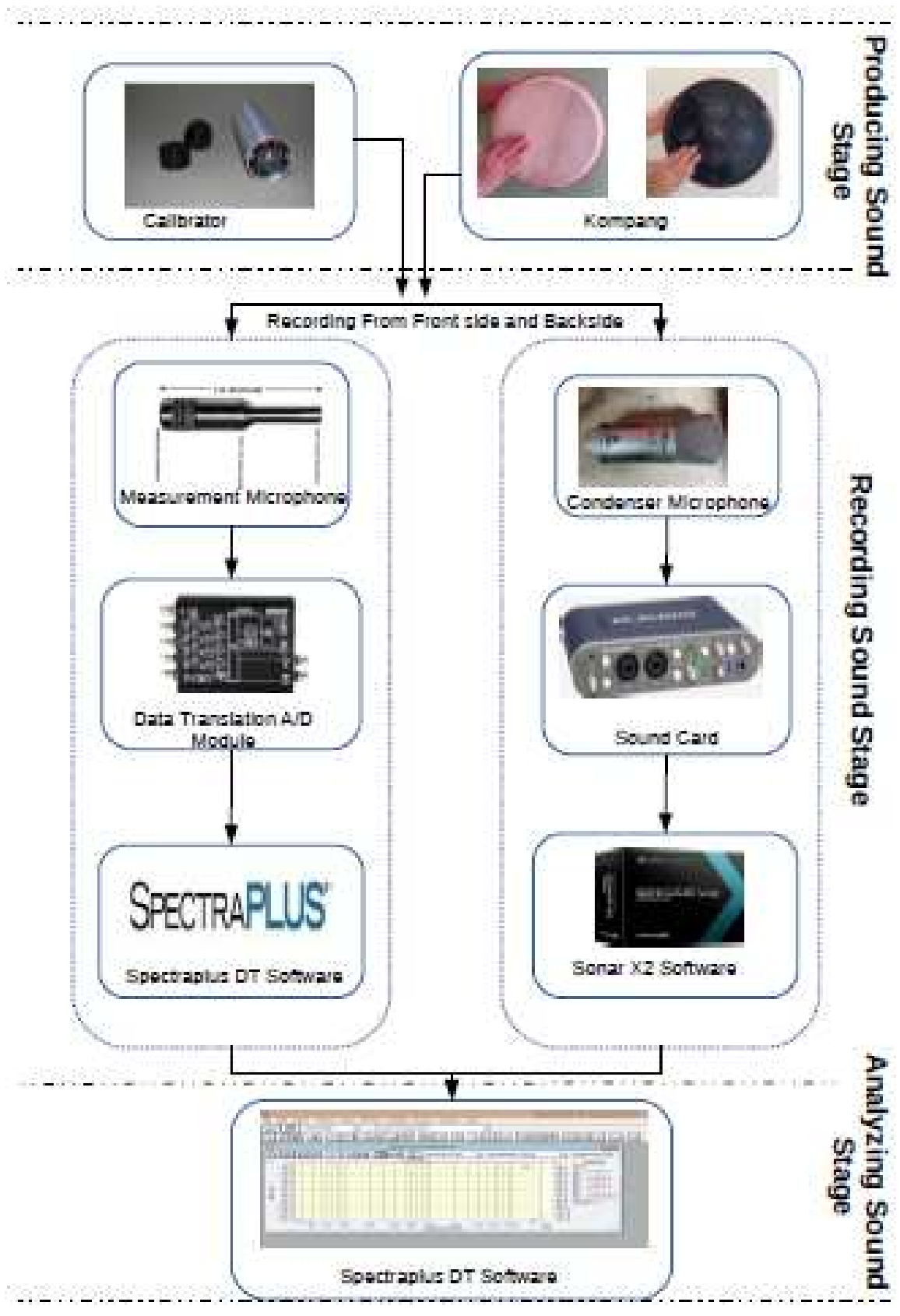

Fig. 3 Sound recording and analyzing.

\section{Results and Discussion}

The sound is obtained from the frontal side of the kompang. Two different types of kompang are considered namely big kompang $(320 \mathrm{~mm})$. The red line represents the membrane made of polymer while green line for the membrane made of animal skin. Fig. 4 reveals the frequency responses of big kompang size of "bung" and "pak" sounds, respectively. It is for a big kompang, the sound level for each type of skin is identical. Similar, sound patterns can also be observed for a "pak" strike.

Fig. 5 shows the sound level for a small kompang. If "pak" strike is used, sound level for an animal skin is greater than a polymer skin. However, the peak to peak distances for the polymer skin. In order to have better insight of the sound responses, Table 1 lists some important peak sound responses for comparison purposes. It is indicated that the peak sound for the polymer skin (x-ray film) is higher than the goat skin for both type of kompang. If the small size kompang is used, the sound percentage of error between the both skins are large compared with the big size kompang. 


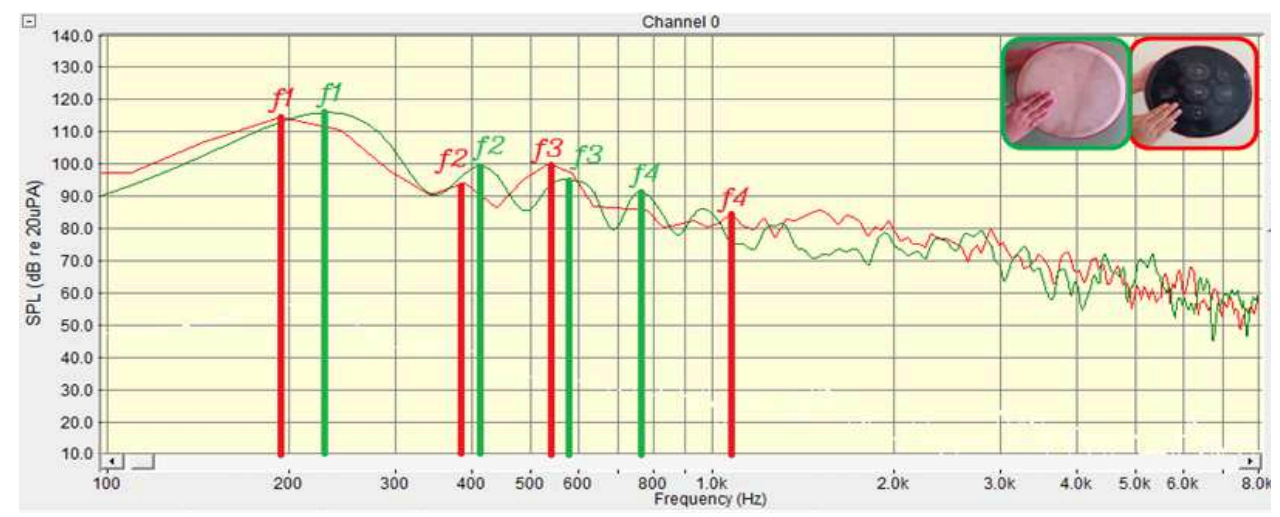

(a)

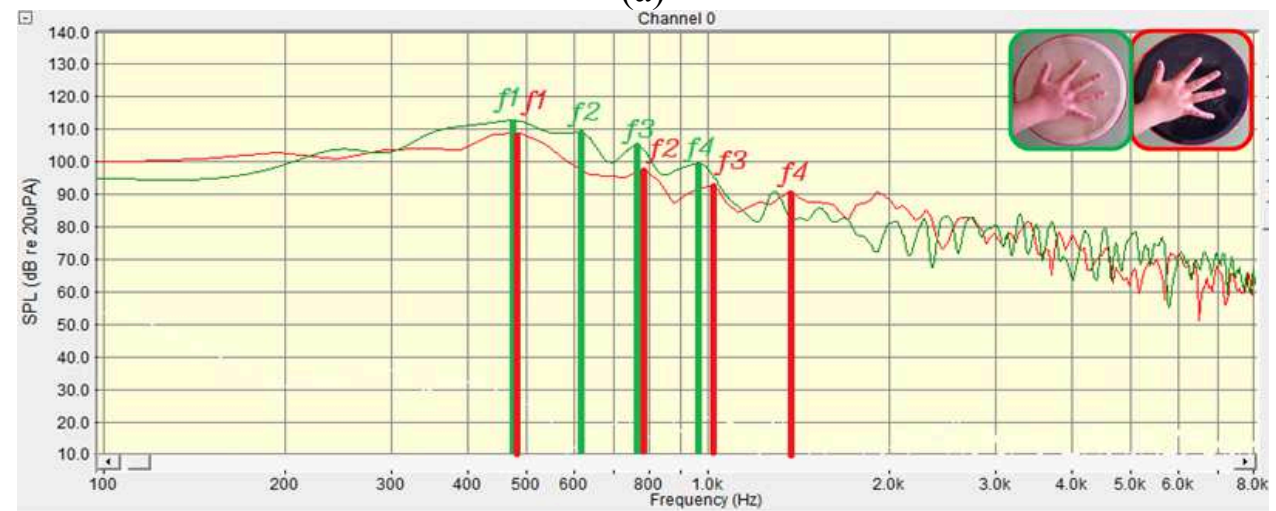

(b)

Fig. 4 Sound level of (a) "bung" and (b) "pak" sounds for a big kompang.

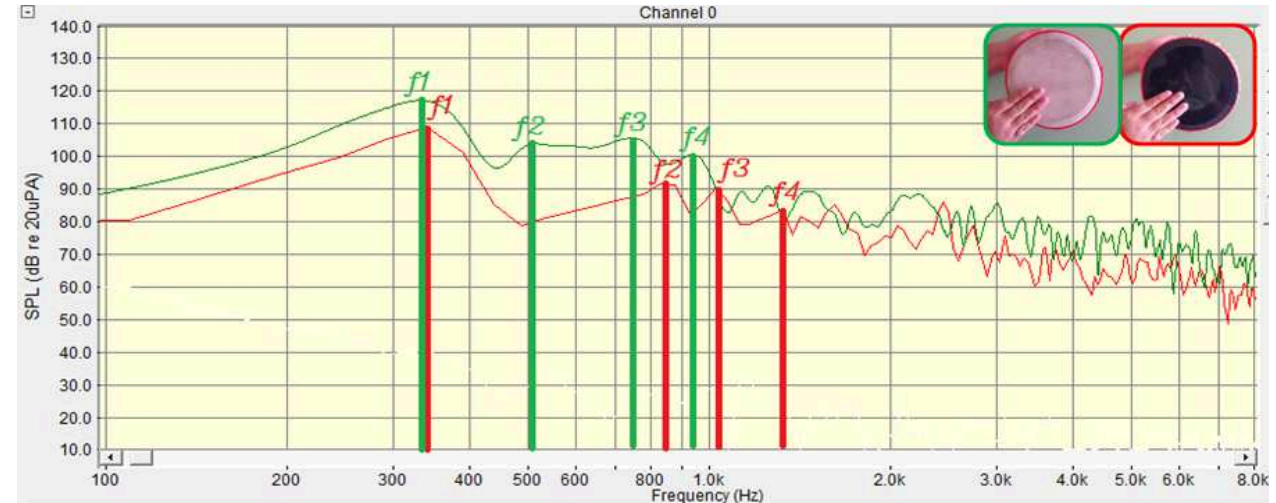

(a)

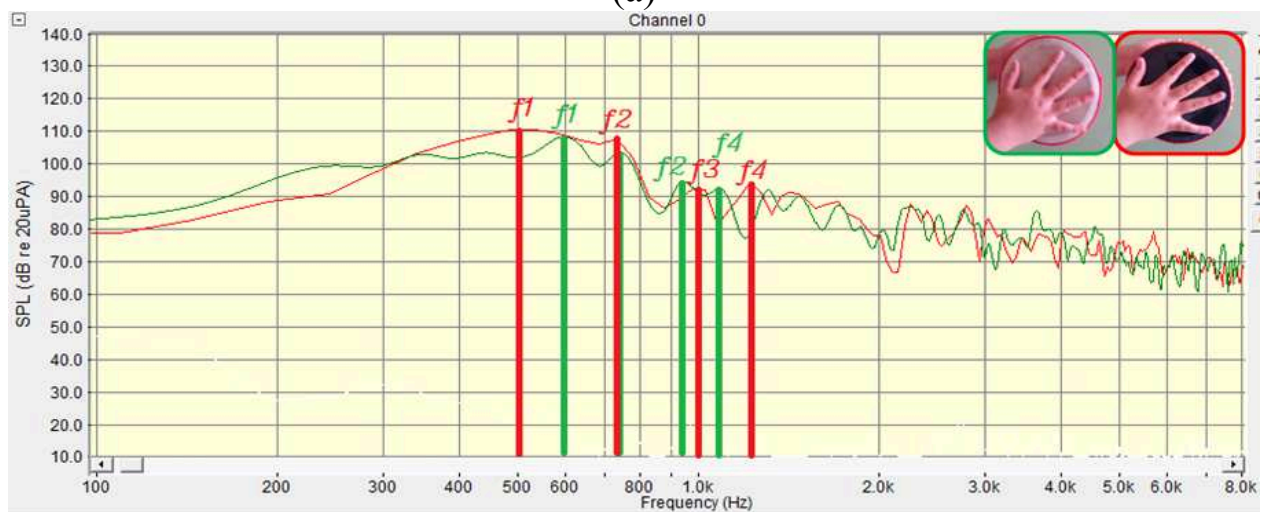

(b)

Fig. 5 Sound level of (a) "bung” and (b) "pak" sounds for a small kompang. 
Table 1 Comparison of peak frequency responses between two different membrane skins.

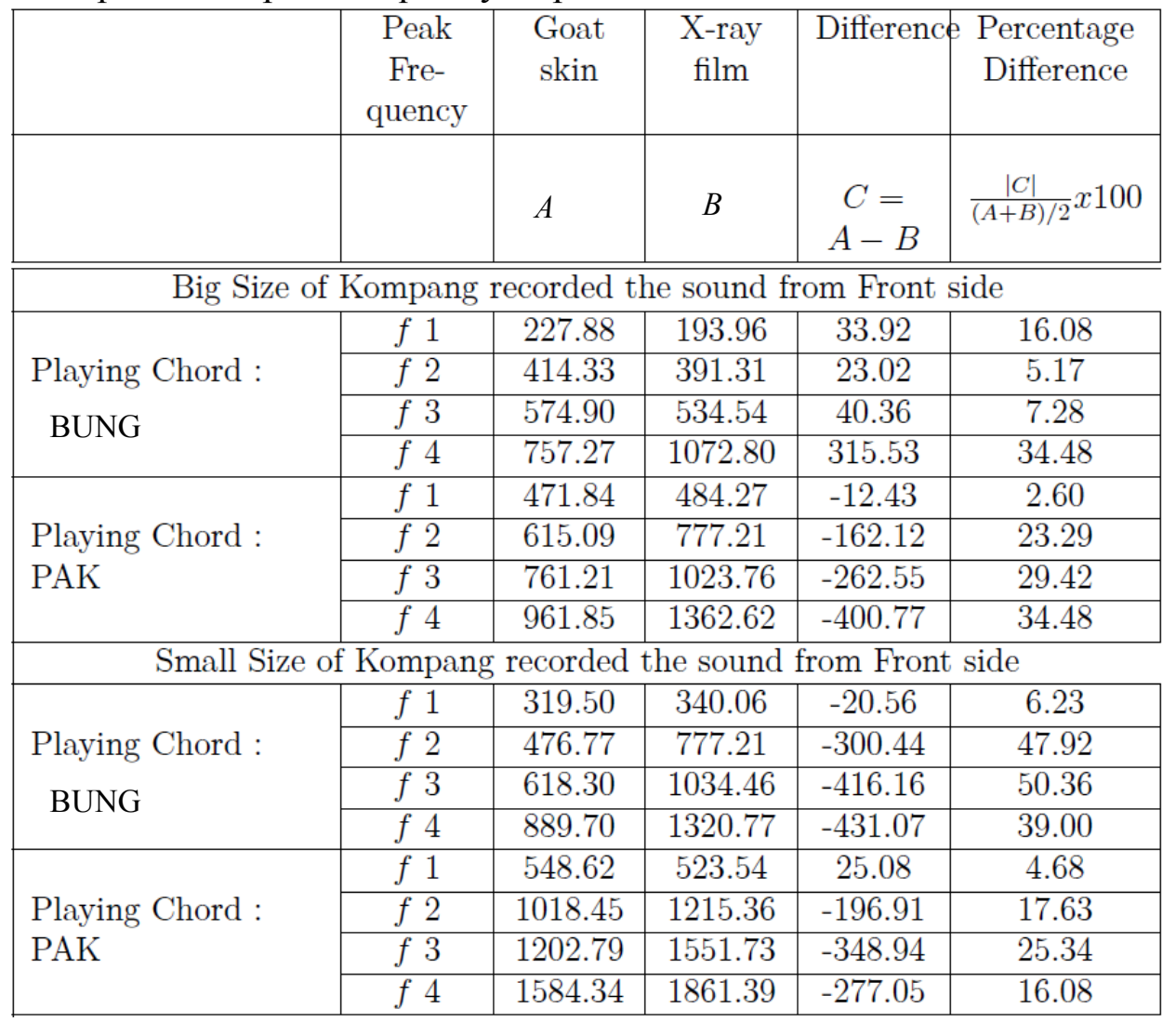

\section{Conclusion}

There are two types of membrane skins used to fabricate the kompang which are polymeric (used xray film) and animal (goat) skins. The sounds produced by these types of kompang produce closely similar sound level however they have their own sound characteristics. According to the present results, animal skins used as a membrane produced $25.34 \%$ lower frequency compared with the polymeric skins. Additionally for a polymeric skin, the distance between the peak frequencies is wider than the peak frequency for an animal skin.

\section{Acknowledgement}

Authors acknowledge Universiti Tun Hussein Onn Malaysia (UTHM), Office for Research, Innovation, Commercialization and Consultancy (ORICC) and Ministry of Education Malaysia for sponsoring this work through Fundamental Research Grant Scheme (FRGS) vot. 1206.

\section{References}

[1] A. Ismail, S.A. Samad, A. Hussain, C. H. H. Azhari and M.R.M.Zainal. Analysis of the Sound of the Kompang for Computer Music Synthesis. 4th Student Conference on Research and Development (SCOReD 2006), Shah Alam, Selangor, MALAYSIA, 27-28 June, 2006.

[2] N. Senan, R. Ibrahim, N.M. Nawi, A Study on Traditional Malay Musical Instruments Sounds Classification System", in proceedings: the 11th International Conference on Information Integration and Web-based Applications \& Services (iiWAS2009),(2009) 729-733.

[3] W.A. Siswanto, L.Tam, M.Z. Kasron, Sound Characteristics and Sound Prediction of the Traditional Musical Instrument the Three-Rattle Angklung. International Journal of Acoustics and Vibration, Vol. 17, No. 3, 2012, 120-126. 